\title{
DETECTION OF REFRACTORY ORGANIC POLLUTANTS FROM PULP PAPER MILL EFFLUENT AND THEIR TOXICITY ON Triticum aestivum; Brassica campestris AND Tubifex-tubifex
}

\author{
Ajay Kumar Singh, Adarsh Kumar, Ram Chandra \\ Department Environmental Microbiology, School for Environmental Science, Babasaheb Bhimrao Ambedkar University, Vidya Vihar, Raibarely Road, Lucknow, 226025 \\ Received - August 11, 2020; Revision - September 28, 2020; Accepted - October 16, 2020 \\ Available Online - October 25, 2020 \\ DOI: http://dx.doi.org/10.18006/2020.8(5).663.675
}

\section{KEYWORDS \\ Pulp paper mill \\ Organic pollutant \\ Toxicity assessment \\ Tubifex-tubifex \\ T. aestivum and B. campestris}

\begin{abstract}
The pulp and paper industry released different chemical pollutants that are directly discharged into the environment without proper treatment. This experiment was carried out to study the effect of pulp paper mill sludge amendments with garden soil $(25 \%, 50 \%, 75 \%$, and $100 \%)$, and garden soil was utilized as a control in a pot experiment. This study revealed the growth parameters of Triticum aestivum and Brassica campestris in germination percentage and germination index values decreased with rising in sludge concentration. Further, Soil amended with $25 \%$ paper mill sludge slightly reduced the growth in root length, shoot length, biomass, photosynthetic, and 50\% sludge amended soil had variable effects on the root, shoot, and photosynthetic pigment of T. aestivumand B. campestris. However, the toxicity of effluent on tubifex-tubifex worms was also carried out at selected concentrations (25\%, 50\%, 75\%, and 100\%). Results of the study suggested that after 24 hours of exposure (>25\% concentration), tubifex worms showed various changes such as morphological changes; hemoglobin content disappeared at the lethal concentrations of pulp paper mill effluent; cell bursting, and the back of the body became white with body disintegration at the lethal concentrations of pulp paper mill effluent. This article mainly focuses on the toxicity of the organic pollutants in terrestrial and aquatic life due to pulp paper mill effluent.
\end{abstract}

* Corresponding author

E-mail: prof.chandrabbau @gmail.com (Prof. Ram Chandra)

Peer review under responsibility of Journal of Experimental Biology and Agricultural Sciences.

Production and Hosting by Horizon Publisher India [HPI] (http://www.horizonpublisherindia.in/).

All rights reserved.
All the articles published by Journal of Experimental Biology and Agricultural Sciences are licensed under a Creative Commons Attribution-NonCommercial 4.0 International License Based on a work at www.jebas.org.

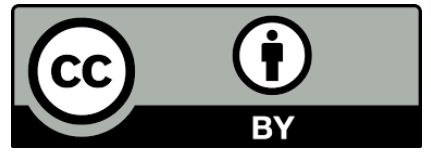




\section{Introduction}

The pulp and paper mill is one of the major pollution-causing industry in the world due to the presence of different types of organic, inorganic, and metallic pollutants in the effluent (Singh \& Chandra, 2019). It generated $150-200 \mathrm{~m}^{3}$ wastewater (effluent) per ton of paper production (Pokhrel \& Viraraghavan, 2004). The discharged wastewater contains $40-45 \%$ raw materials which are loaded with lignocellulose, chlorolignins, fatty acids, chlorinated resins, chlorinated phenols, chlorophenols, pesticides, and biocides i.e., collectively known as organic pollutants (Lindholm-Lehto et al., 2015). These organic pollutants may be mutagenic, carcinogenic, endocrine-disrupting, and clastogenic due to high biological oxygen demand (BOD), chemical oxygen demand (COD), total dissolved solids (TDS), and total suspended solids (TSS) in wastewater (Karrasch et al., 2005; Yadav \& Chandra, 2018). Besides these, some trace elements are also present in the effluent limit which can cause toxicity in crops. The organic component of effluent provides natural media for the growth of pathogenic microorganisms which is also harmful to humans (Chandra et al., 2006; USEPA, 2012). However, toxic effects of the effluent in the natural ecosystem are also noticed such as color problems, thermal impacts, scum formation, slime growth, and loss of biodiversity (Zhang et al., 2013; Jaramillo \& Restrepo, 2017). It may be a dangerous sign to the survival of animals and crops. The refractory chemical compounds are also released during the chemical bleaching and paper making process i.e. chlorolignins, chlorophenols, and biocides are persistent in nature and bioaccumulate in the fatty tissues of the tubifex worms which are characterized as lipophilic compounds, that are capable to easily penetrate the cell membrane (Lindholm-Lehto et al., 2015; Kumar et al., 2020). The derivatives of effluent chemical compounds are accumulated in the plant and tubifex-tubifex worm and also reached into the trophic level via the food chain into the natural ecosystem (Raj et al., 2007; Kumar et al., 2020). However, the chlorophenols derivatives cause adverse effects on the food chain in the environment and the adverse effect was noticed on the primary, secondary and tertiary consumers (Colette \& Kevin, 2017). The Organization for Economic Co-operation and Development (OECD) guideline the wheat and mustard crops are valuable worldwide for cultivation in the agricultural field. Hence these plants are used as model test crops in research.

However, the knowledge of the refractory organic pollutants of paper mill effluent is not much known. Hence, this article provides clear and advance knowledge about the toxic properties of chemicals released with effluent from the paper industry. However, there are many treatment methods are available (i.e. physical, chemical, and biological) for reduction and remediation of color and toxicity of the effluent but, in these processes high molecular weight chemical compounds, toxicants, dissolved solids, suspended solids, and low molecular weight compounds are not removed properly and method is highly cost-effective (Hossain \& Ismail, 2015). Besides, low molecular weight compound contains chlorinated ring structure in pentachlorophenol (PCP) it is anticipated to be recalcitrant to aerobic biodegradation in running wastewater. Whereas, aromatic compounds with greater chlorine levels are usually highly resistant towards biodegradation and biotransformation. According to the US Environmental Protection Agency (USEPA, 2012), PCP is a priority pollutant and is found higher than the permissible limit $\left(0.30 \mu \mathrm{g} / \mathrm{l}^{-1}\right)$ even after tertiary treatment. Pulp paper mill effluent contains heavy metals that cause a toxic effect in the crop plants as well as heavy metals accumulate in the roots, stems, and leaves and also stored in the seeds of the plants and affect the food chain (Reza et al., 2015).

The present study has been focused on the detection of organic pollutants released from pulp paper mill and their toxicity has been checked on T. aestivum and B. campestris (terrestrial model) and Tubifex-tubifex (an aquatic model organism). It showed pulp paper mill effluent cannot be useful for irrigation due to their toxic properties in the environment.

\section{Materials and methods}

\subsection{Sample collection and analysis}

The effluent and sludge samples were collected from the Yash paper mill Faizabad (U.P.), India and kept at $4{ }^{0} \mathrm{C}$ icebox container for further analysis.

\subsection{Physico-chemical analysis of the pulp paper mill effluent}

The Standard for the examination of water and wastewater standard methods (APHA, 2005) was followed for the analysis of physicochemical parameters of effluent and sludge samples. Physico-chemical parameters i.e. biological oxygen demand (BOD), total dissolved solids (TDS), chemical oxygen demand (COD), phosphate, total phenol, total nitrogen, and sulfate were analyzed (APHA, 2005). The color was measured by using a Canadian pulp and paper Association conventional technique at $465 \mathrm{~nm}$ by UV-visible spectrophotometer 2300 (Evolution 201) (CPPA, 1994), $\mathrm{pH}$ of the sample was evaluated using a $\mathrm{pH}$ meter (Water and Soil Analysis Kit ESICO 1160) and dissolved oxygen was measured using a Clark polarographic dissolved oxygen sensor (835 A, Germany) $0.1 \mathrm{mg} / \mathrm{l}$. Lignin content was measured as per the Pearl \& Benson (1940). Heavy metals and various ions such as chloride, sodium, potassium, and nitrogen were estimated by atomic absorption spectrophotometer (AAS) and by the selective ion electrodes (Orion Model 960). Sugar content was estimated by the phenol sulfuric acid method (Chow \& Landhausser, 2004). 
2.3 Extraction and identification of various refractory organic compounds

The organic refractory compounds present in effluent and sludge were extracted by dichloromethane (DCM) at $\mathrm{pH}$ 8.0. An aliquot of the concentrate was dissolved in $3.0 \mathrm{~mL}$ DCM, filtered through $0.22-\mu \mathrm{m}$ syringe filters, and used for further Gas-chromatography and mass spectrometry (GC-MS) analysis.

\subsection{Gas-chromatography and mass spectrometry analysis of} refractory organic pollutants

Before the characterization of the refractory organic pollutants, various organic solvents i.e., acetone, dichloromethane, n-hexane, methanol, and isopropyl alcohol, were tested to compare the ability to extract residual organic pollutants, and dichloromethane was found to be optimal. The GC-MS analysis of the dichloromethane extracts was performed following the method described by Chandra et al. (2009) for the characterization of the residual organic pollutants. The residual organic pollutants were identified by comparing their mass spectra with those provided in the National Institute of Standards and Technology (NIST) library, which was supplied with the instrument.

\subsection{Toxicity assessment by pot experiment test}

To analyze organic pollutant toxicity in T. aestivum and B.campestris using pulp paper mill wastewater and sludge. A pot experiment was conducted at the research field of Bioremediation and Metagenomics under the greenhouse condition in the Department of Environmental Microbiology, Babasaheb Bhimrao Ambedkar University Lucknow, India, 226025.

Thirty-two pots were filled with three $\mathrm{kg}$ of soil mixed with a sludge sample. The wheat and mustard variety (UP-2338 and B17) were sown in eight sets each set contains four pots, two control sets (filled with agricultural soil one set for UP-2338 and second forB-17). While the remaining six sets were treated with various amount of pulp paper mill sludge amended with agricultural soil. Twenty seeds of selected wheat (UP-2338) and mustard variety (B17) were sown in each pot. However, the remaining six sets were filled with different concentration of sludge with an agricultural soil viz., (i) $25 \%$ sludge and $75 \%$ agricultural soil; (ii) $50 \%$ sludge and $50 \%$ agricultural soil; (iii) $75 \%$ sludge and $25 \%$ agricultural soil, and (iv) $100 \%$ sludge. Three replicates of the selected crop were made for each treatment. Plants were irrigated through pulp paper mill wastewater as per requirement. Different morphological parameters of different varieties of wheat and mustard were also observed. The maturation period for both crops was 5 months, so plants were harvested in April 2019.

\subsection{Tubifex-tubifex toxicity}

Tubifex worms were collected from Gomati River, Lucknow, Uttar Pradesh India from natural sources and acclimatized in laboratory conditions for 7 days before the experiment. Ten tubifex worms were exposed for $96 \mathrm{~h}$ of each concentration $(25 \%, 50 \%, 75 \%$, and $100 \%$ ) through direct effluent sample and $0 \%$ (tap water) used as control. When they were fully immobilized and no reaction pressed with a blunt glass rod, test worms were regarded to be dead. Death was further verified by returning worms to tap water with new control. Every 24 hours, test water was renewed and the experiment was conducted in triplicate.

\subsection{Statistical analysis}

For the statistical analysis, of variance (Twoway ANOVA) by student T-test statistics and means were compared by Duncan's multiple range test (DMRT) (Duncan, 1955).

\section{Results and discussion}

\subsection{Physico-chemical parameters}

Physicochemical parameters of paper mill effluent showed dark brown color, foul odor, and turbid. It might be the presence of polymeric lignin degradation products formed during the black liquor stage of pulping(Chandra \& Abhishek, 2010; Chandra \& Yadav, 2017). Color in the effluent is usually associated with aromatic compounds produced from the decay of organic pollutants which were released from the paper industry. However, dark colours can cause the problems of both water opacity and the blanketing of the river. The dark colour and blanketing can reduce photosynthetic activity in aquatic plants (Singh \& Thakur, 2004). This leads to a chain of adverse effects on the aquatic ecosystem as the growth of primary consumers as well as secondary and tertiary consumers are adversely affected (Ruggicro et al., 1989). The color of effluent also depends on $\mathrm{pH}$ and it was recorded slightly alkaline (7.89 \pm 0.53$)$. Slightly alkaline $\mathrm{pH}$ was the result of the bleaching process during paper manufacturing and it was not beyond the permissible limit (Livernoche et al., 1983). The low pH values could be the result of organic acids caused by the fungal metabolism and the high $\mathrm{pH}$ level is the result of paper bleaching (Holt et al., 2008). The concentration of BOD $\left(788 \pm 3.16 \mathrm{mg} / \mathrm{l}^{-1}\right)$ and COD $\left(416 \pm 2.13 \mathrm{mg} / \mathrm{l}^{-1}\right)$ was observed high in the effluent. The high amount of BOD and COD value in effluent indicates the presence of organic and inorganic-organic pollutants in the effluent (Yadav \& Chandra, 2018). It might be due to the presence of cellulose, hemicelluloses, lignin, xylose, chlorinated phenolic compounds, and other related compounds used in the bleaching and wood digestion process. During wood digestion sodium hydroxide and sodium sulfide were used for fibers separation in the dissolving tank. After that, fibers removed and the remaining water was treated as black liquor. Due to the caustic nature of black liquor, it is expected that there would be toxic effects (e.g. edema) to the respiratory system if mists or vapors are inhaled and toxic effects for skin and eye exposures, especially at elevated 
temperatures (Singh \& Chandra, 2019). The toxicity ranking above is associated with representative components of the black liquor (sodium sulfide and sodium hydroxide, etc.) which are presented as a determination of acute toxicity of complex mixture by analogy. The chloride $\left(1942 \pm 8.45 \mathrm{mg} / \mathrm{l}^{-1}\right)$ and sulfate $(136 \pm 2.21$ $\mathrm{mg} / \mathrm{l}^{-1}$ ) ions were found to be at optimum level and were generated from bleaching and sodium sulfite processes (Singh \& Chandra, 2019). One particular study, conducted by Wurtz \& Bridges (1961), including two of the four species suspected of being most sensitive to chloride (a Iowa DN planorbid snail, Gyraulus circumstriatus, and the fingernail clam, Sphaeriu mtenue). Further, Khangarot (1991) suggested acute chloride toxicity data for the tubificid worm (Tubifex-tubifex), which indicated that this species might also be highly sensitive to chloride. Phosphate (70.86 \pm 1.16$)$ was found below the permissible limit in the effluent sample and higher in the sludge $(1223.62 \pm 46.47)$ and garden soil $(886.78 \pm 16.53)$. The same results were also reported by Singhal \& Thakur, (2009). Phosphate has the potential to cause increased algal growth leading to eutrophication in the aquatic environment. However, there is no adequate information available on risk assessment or acute and chronic toxicity.

The elevated level of chemical parameters in the effluent due to lignocellulosic raw materials used in the manufacturing process wood digestion, pulping, bleaching, paper making, and chemical recovery (Chandra \& Singh, 2012).The heavy metals were recorded as $\mathrm{Cd}\left(0.618 \pm 0.12 \mathrm{mg} / \mathrm{l}^{-1}\right), \mathrm{Cu}\left(2.156 \pm 0.22 \mathrm{mg} / \mathrm{l}^{-1}\right), \mathrm{Fe}$ $\left(6.384 \pm 0.89 \mathrm{mg} /^{-1}\right), \mathrm{Ni}\left(2.148 \pm 0.21 \mathrm{mg} /^{-1}\right), \mathrm{Pb}(0.265 \pm 0.11$ $\left.\mathrm{mg} /^{-1}\right)$, and $\mathrm{Zn}\left(3.245 \pm 1.51 \mathrm{mg} /^{-1}\right)$ was recorded in the paper mill effluent. All metals were found at an optimum level as per the permissible limit except iron. Due to heavy metals, serious health hazards are caused due to the transfer of these contaminants into the food chain (Singh \& Chandra, 2019). Due to changing environmental conditions and extreme use of agrochemical heavy metals in the paper industry are being accumulated in soils that are transferred to the water system by leaching. This poses a serious threat to human life and the environment (Nicholson et al., 2003; Wong et al., 2003). However, the ingestion of large quantities of iron results in hemochromatosis. It is a condition in which normal regulatory mechanisms do not operate effectively which leads to tissue damage as a result of the accumulation of iron. The details of the analyzed physicochemical parameters were shown in table 1.

\subsection{Characterization of refractory organic pollutants from pulp paper mill effluent}

The extracted effluent and sludge samples were characterized through showed various peaks at different retention times (RT) (figure 1.a, b). In the effluent sample, major peaks recorded at RT 27.33 and 43.52,were characterized as docosane; tetradecane; hexadecaneand 1,8-diphenyl-3,4,10,11-tetrahydro[1,4]dioxino[2,3g:5,6-g']diisoquinoline, 3-á-acetyl-7-azidocholesterol, respectively (table 2). However, minor peaks were observed at different RT7.80, 10.37, 12.89, 17.47, 21.54, 25.18, 31.30, 37.06, and 48.15 and interpreted as the hexadecane, 2-methyl-, ; methyl 1iodomethyl-2-oxocyclotetradecanoate; eicosane, heptadecane, octadecane, pentadecane; tricosane, eicosane, dodecane; dodecane, hexadecane, octadecane; docosane, tetradecane, hexadecane; pentachlorobromobenzene, rans, trans-alloocimene; 9 (1,1-(2)H(2)-ethyl) anthracene, bis(3,4-dimethoxycinnamoyl)-Ltartaric acid, 4-Cyano-2-methyl-N-phenylacetanilide and $5,11,17,23$, tetrakis (1,1dimethylethyl) 28methoxypentacyclo [19.3.1.1(3,7).1(9,13).1(15,19)]

octacosa1(25),3,5,7(28),9,11,13(27),15,17,19(26),21,23-dodecene$25,26,27$-triol, respectively in the effluent (Table 2). These organic compounds were also generated by degradation, migration, and transformation processes during water movement after released from the industry (Yadav \& Chandra, 2018). However, larger molecules of organic matter can be formed from the polymerization of different parts of the already broken down matter. The composition of natural organic matter depends on its origin, transformation mode, age, and existing environment, thus its bio-physicochemical functions vary with different environments (Nicola et al., 2006).

The hexadecane was detected in the GC-MS analysis from the effluent sample which is used as biocides in the paper industry and kraft recovery process. This compound can cause different problems to humans such as lung irritants, endocrine-disrupting chemicals, headache, dizziness, tiredness, nausea, vomiting, depression, and gastrointestinal tract irritation (Singh \& Chandra, 2019). Decane, undecane, and dodecane were recorded for cytotoxicity at high concentrations. However, tetradecane, pentadecane, and hexadecane were reported for hematotoxicity. The mixed solvent of chemical compounds was toxic to human epidermal keratinocytes (Yang et al.,2006). The organic pollutants octadecane, pentachlorobromobenzene, tricosane, and methyl 1iodomethyl-2-oxocyclotetradecanoate, may also be produced from the pulp bleaching and biocide used as a preservative which has toxic properties, it may act as endocrine-disrupting chemicals and also very toxic to aquatic life (Yadav \& Chandra, 2018). The other pollutants may also report for causes toxicity to the environment which is listed in table 2 .

However, the refractory organic pollutants that were detected in the sludge sample showed a measure peak at RT 6.17, 3mercaptobenzoic acid, tertbutyldimethylsilyl ester compounds were detected and released from the wood extract during the digestion process. It may cause eye, skin irritation, and respiratory problems. The compound octadecane; hexacosane; tetradecane was detected at RT 7.79 which was generated from the bleaching process and have Endocrine-Disrupting chemical properties (EDCs). The octadecane properties of EDCs were also reported (USEPA, 2012; Yadav \& 
Table 1 Physico-chemical parameters of pulp paper mill effluent, sludge and garden soil used in the experiment

\begin{tabular}{|c|c|c|c|c|}
\hline Parameters & KR pulp paper effluent & KR pulp paper sludge & Garden soil & $\begin{array}{l}\text { Permissible limit } \\
\text { (USEPA 2012) }\end{array}$ \\
\hline $\mathrm{pH}$ & $7.89 \pm 0.53$ & $8.81 \pm 0.21$ & $7.54 \pm 0.32$ & $5-9$ \\
\hline Color & - & - & - & - \\
\hline BOD & $788 \pm 3.16$ & - & - & 40 \\
\hline COD & $416 \pm 2.13$ & - & - & 120 \\
\hline $\mathrm{EC}$ & - & $2.92 \pm 0.24$ & $2.12 \pm 0.12$ & - \\
\hline Moisture (\%) & - & $78 \pm 2.0$ & $56 \pm 1.6$ & - \\
\hline Organic matter (\%) & - & $19.76 \pm 0.84$ & $0.74 \pm 0.53$ & - \\
\hline Phosphate & $70.86 \pm 1.16$ & $1223.62 \pm 46.47$ & $886.78 \pm 16.53$ & 250 \\
\hline Chloride & $1942 \pm 8.45$ & $2759.54 \pm 28.25$ & $1112.57 \pm 8.21$ & 1500 \\
\hline Sulphate & $136 \pm 2.21$ & $168.24 \pm 8.62$ & $88.69 \pm 6.51$ & 250 \\
\hline Phenol & - & $458.97 \pm 27.03$ & $64.84 \pm 1.32$ & 0.50 \\
\hline Sodium & - & $97.86 \pm 2.43$ & $46.26 \pm 5.12$ & 200 \\
\hline Total Nitrogen & $216 \pm 4.23$ & $478.66 \pm 32.06$ & $178.19 \pm 8.46$ & 143 \\
\hline Lignin & $467 \pm 5.86$ & - & - & \\
\hline \multicolumn{5}{|l|}{ Heavy metals } \\
\hline $\mathrm{Cu}$ & $2.156 \pm 0.22$ & $112.37 \pm 1.57$ & $16.28 \pm 0.94$ & 0.50 \\
\hline $\mathrm{Cr}$ & $2.758 \pm 0.91$ & $6.12 \pm 0.21$ & $5.37 \pm 0.18$ & 0.05 \\
\hline $\mathrm{Cd}$ & $0.618 \pm 0.12$ & $1.85 \pm 0.52$ & $0.49 \pm 0.12$ & 0.01 \\
\hline $\mathrm{Fe}$ & $6.384 \pm 0.89$ & $78.22 \pm 2.03$ & $26.78 \pm 1.53$ & 2.00 \\
\hline $\mathrm{Pb}$ & $0.265 \pm 0.11$ & $8.24 \pm 0.62$ & $3.86 \pm 0.35$ & 0.05 \\
\hline $\mathrm{Zn}$ & $3.245 \pm 1.51$ & $124.64 \pm 7.24$ & $72.35 \pm 3.15$ & 2.00 \\
\hline $\mathrm{Ni}$ & $2.148 \pm 0.21$ & $23.54 \pm 2.64$ & $11.92 \pm 1.64$ & 0.10 \\
\hline
\end{tabular}

All the units are in $\mathrm{mg} / \mathrm{L}$ except $\mathrm{pH}$ and color


Figure1. The chromatogram of refractory organic pollutants extracted with dichloromethane from pulp and paper industry: (A) Effluent sample and (B) Sludge sample

Journal of Experimental Biology and Agricultural Sciences http://www.jebas.org 
Table 2 Refractory organic pollutants detected from the effluent sample by GC-MS at different retention time (RT) and their toxicity

\begin{tabular}{|c|c|c|c|c|}
\hline S.No. & RT & Compounds & Sources & Toxicity \\
\hline 1. & 7.80 & Hexadecane, 2-methyl- & Plant, biocides & $\begin{array}{l}\text { Very hazardous in case of inhalation (lung irritant). } \\
\text { Hazardous in case of skin contact (irritant, } \\
\text { sensitizer), of ingestion, }\end{array}$ \\
\hline 2. & 10.37 & Methyl 1-iodomethyl-2-oxocyclotetradecanoate & Plant & Endocrine-Disrupting chemical \\
\hline 3. & 12.89 & Eicosane; Heptadecane; Octadecane; Pentadecane & Bleaching & $\begin{array}{l}\text { accumulate and harm fish in aquatic ecosystem; } \\
\text { Endocrine-Disrupting chemicals }\end{array}$ \\
\hline 5. & 17.47 & Tricosane; Eicosane; Dodecane & Pulping & Very toxic to aquatic life \\
\hline 6. & 21.54 & Dodecane; Hexadecane; Octadecane & $\begin{array}{l}\text { Pulp bleaching, } \\
\text { Biocides }\end{array}$ & eye and skin irritation \\
\hline 7. & 25.18 & Hexadecanoic acid, trimethylsilyl ester & Effluent, biocides & $\begin{array}{l}\text { Endocrine-Disrupting, headache, dizziness, } \\
\text { tiredness, nausea and vomiting }\end{array}$ \\
\hline 8. & 27.33 & Docosane; Tetradecane; Hexadecane & Plant essential oil & $\begin{array}{lcccc}\begin{array}{l}\text { Central Nervous } \\
\text { gastrointestinal tract irritation }\end{array} & \text { depression, and } \\
\end{array}$ \\
\hline 9. & 31.30 & $\begin{array}{l}\text { Pentachlorobromobenzene; } \\
\text { rans,trans-alloocimene }\end{array}$ & Plant essential oil & Endocrine-Disrupting \\
\hline 10. & 37.06 & $\begin{array}{l}\text { 9-(1,1-(2)H(2)-ethyl)anthracene; } \\
\text { Bis(3,4-dimethoxycinnamoyl)-L-tartaric acid; } \\
\text { 4-Cyano-2-Methyl-N-phenylacetanilide }\end{array}$ & Bleaching, biocides & $\begin{array}{l}\text { headache, nausea, vomiting, diarrhea and abdominal } \\
\text { pain }\end{array}$ \\
\hline 12. & 43.52 & $\begin{array}{l}\text { 1,8-Diphenyl-3,4,10,11-tetrahydro[1,4]dioxino[2 } \\
\text {,3-g:5,6-g']diisoquinoline; } \\
\text { azidocholesterol }\end{array}$ & Biocides, Plant & Asthma, Carcinogen \\
\hline 14. & 48.15 & $\begin{array}{l}\text { 5,11,1723-tetrakis(1,1-dimethylethyl)-28- } \\
\text { methoxypentacyclo[19.3.1.1(3,7).1(9,13).1(15,19)] } \\
\text { octacosa1(25),3,5,7(28),9,11,13(27),15,17,19(26),2 } \\
\text { 1,23-dodecene-25,26,27-triol }\end{array}$ & Bleaching & Genotoxic, cytotoxic \\
\hline
\end{tabular}

Chandra, 2018). However, pentasiloxane, dodecamethyl- was detected at RT 10.37 and released from the bleaching and paper making process that causes toxicity to the aquatic ecosystem and accumulate in fish and other organisms through the food chain. The chemical compounds tricosane; hexadecane, 2-methyl-; octadecane, 1-iodo- was detected at RT 21.52 which was released from the paper industry and these were used as biocides in the paper preservation process. It may cause skin problems (irritant, sensitizer, lung irritant) and lung cancer also. The oleic acid, trimethylsilyl ester; trans-9Octadecenoic acid, compound were also detected in GC-MS at RT 29.84 and they are generated from the plant essential oil. The acute exposure was noticed due to plant essential oils such as the central nervous system (CNS) depression, and gastrointestinal tract irritation. However, tetratetracontane; nonacosane compound was found at RT 38.61 that causes headache, nausea, vomiting, diarrhea and abdominal pain which were generated from the bleaching process of the paper mill (Yadav \& Chandra, 2018). The compound 1,8-Diphenyl-3,4,10,11-tetrahydro[1,4]dioxino[2,3-g:5,6-

g']diisoquinoline; 3-á-Acetyl-7-azidocholesterol was found at RT 43.51 which was used as biocides in paper making process causes asthma to a human being. The organic compound meso-2-Nitro5,10,15,20-tetra (4-pyridyl) porphyrin; 1,4- Bis [3,5-bistrimethylsilylethynylphenyl) ethynyl] benzene was detected at RT 48.12 from the paper industry which was released after the bleaching process in the effluent that causes acute toxicity; acute exposure to hexadecane causes irritation, CNS depression, and gastrointestinal tract irritation (Kim et al., 2016). However, some other compounds were also detected which were shown in table 3. Above mentioned toxic organic compounds were released directly into the environment as effluent that has different toxic properties which are listed in USEPA, 2012. These compounds leached out into the groundwater which causes health hazards in human beings.

\subsection{Pot experiment test}

The toxicity of effluent and sludge was evaluated based on percentage germination and toxicity percentage as per the method followed by Oljira et al. (2018). The growth parameters of plants i.e. germination percentage; root length; shoot length; leaf number and total dry weight produced was measured immediately with the help of the centimeter scale after harvesting (Subramani et al., 1997; Ramana et al., 2002). The plant was dried at $72^{\circ} \mathrm{C}$ for $72 \mathrm{~h}$ for dry weight estimation (Wong et al., 1996). According to Arnon's method (Arnon, 1949), chlorophyll content was estimated of both treated and untreated (control) fresh leave samples by spectrophotometer. After secondary treatment of effluent, it was reported to cause significant effects on seed germination parameters due to its potentially toxic nature as revealed by physicochemical characterization. The result of germination as well 
Table 3 Refractory organic pollutants detected from sludge sample by GC-MS at different retention time (RT) and their toxicity

\begin{tabular}{|c|c|c|c|c|}
\hline S.No. & RT & Compounds & Sources & Toxicity \\
\hline 1. & 6.17 & $\begin{array}{l}\text { 3-Mercaptobenzoic acid, } \\
\text { S-(tert-butyldimethylsilyl)-, } \\
\text { tert-butyldimethylsilyl ester }\end{array}$ & Wood extract & $\begin{array}{l}\text { Causes skin irritation, Causes serious eye irritation cause } \\
\text { respiratory irritation }\end{array}$ \\
\hline 2. & 7.79 & Octadecane; Hexacosane; Tetradecane & Plant & $\begin{array}{l}\text { Endocrine-Disrupting, headache, dizziness, tiredness, } \\
\text { nausea and vomiting. }\end{array}$ \\
\hline & 10.37 & Pentasiloxane, dodecamethyl- & Bleaching & accumulate and harm fish in aquatic ecosystem \\
\hline 3. & 12.89 & Octadecane; Pentadecane & Biocide & Endocrine-Disrupting \\
\hline 4. & 17.46 & Tetradecane, 1-iodo-; Octadecane, 1-iodo- & & Very toxic to aquatic life \\
\hline 5. & 21.52 & $\begin{array}{l}\text { Tricosane; Hexadecane, 2-methyl-; Octadecane, 1- } \\
\text { iodo- }\end{array}$ & biocide & $\begin{array}{l}\text { Very hazardous in case of inhalation (lung irritant). } \\
\text { Hazardous in case of skin contact (irritant, sensitizer), of } \\
\text { ingestion }\end{array}$ \\
\hline 6. & 25.17 & $\begin{array}{l}\text { Octadecane, 1-iodo-; Hexadecane, 1-iodo-; } \\
\text { Tricosane }\end{array}$ & $\begin{array}{c}\text { Pulp } \\
\text { bleaching }\end{array}$ & eye and skin irritation \\
\hline 7. & 28.48 & Docosane; Docosane, 11-decyl-; Heptacosane & Effluent & $\begin{array}{l}\text { Endocrine-Disrupting, headache, dizziness, tiredness, } \\
\text { nausea and vomiting }\end{array}$ \\
\hline 8. & 29.84 & $\begin{array}{l}\text { Oleic acid, trimethylsilyl ester; trans-9- } \\
\text { Octadecenoic acid, }\end{array}$ & $\begin{array}{c}\text { Plant } \\
\text { essential oil }\end{array}$ & $\begin{array}{l}\text { Acute exposure to hexadecane causes irritation, CNS } \\
\text { depression, and gastrointestinal tract irritation }\end{array}$ \\
\hline 9. & 34.84 & Pentatriacontane; Eicosane; Docosane & $\begin{array}{c}\text { Plant } \\
\text { essential oil }\end{array}$ & $\begin{array}{l}\text { Acute exposure to hexadecane causes irritation, CNS } \\
\text { depression, and gastrointestinal tract irritation }\end{array}$ \\
\hline 10. & 38.61 & Tetratetracontane; Nonacosane & $\begin{array}{l}\text { Propionic acid } \\
\text { is a naturally } \\
\text { occurring } \\
\text { carboxylic } \\
\text { acid }\end{array}$ & headache, nausea, vomiting, diarrhea and abdominal pain \\
\hline 11. & 39.97 & $\begin{array}{l}\text { 2-phenylseleno-3-(dimethylamino)-1,4-naphthoq } \\
\text { Uinone; 1H-Purin-6-amine, [(2- } \\
\text { fluorophenyl)methyl]- }\end{array}$ & Effluent & Skin, eye, and cause respiratory irritation, \\
\hline 12. & 43.51 & $\begin{array}{l}\text { 1,8-Diphenyl-3,4,10,11-tetrahydro[1,4]dioxino[2 } \\
\text {,3-g:5,6-g']diisoquinoline; 3-á-Acetyl-7- } \\
\text { azidocholesterol }\end{array}$ & Plant tissue & Asthma \\
\hline 13. & 48.12 & $\begin{array}{l}\text { meso-2-Nitro-5,10,15,20-tetra(4-pyridyl)porphyrin; } \\
\text { 1,4-Bis[3,5-bis- } \\
\text { trimethylsilylethynylphenyl)ethynyl]benzene }\end{array}$ & $\begin{array}{l}\text { Plant } \\
\text { essential oil }\end{array}$ & $\begin{array}{l}\text { Acute exposure to hexadecane causes irritation, CNS } \\
\text { depression, and gastrointestinal tract irritation }\end{array}$ \\
\hline
\end{tabular}

as seedling growth of T.aestivum and B.campestris seeds in different concentrations $(25,50,75$, and $100 \%)$ of sludge sample with agricultural soil and irrigated by effluent as presented in table 4 . The seedling growth compared with control, root lengths and shoots of seedling were highest at $25 \%(\mathrm{w} / \mathrm{w})$ sludge and afterword gradually decreased with increasing sludge concentrations. The phytotoxicity was maximum at higher sludge concentration and minimum at lower sludge concentration. This might be associated with the presence of highly toxic complex organic pollutants, toxic metals in pulp paper mill effluent, and sludge. The toxicity of sludge might be responsible for inhibiting the growth parameters. It has been reported that the various highly toxic complex organic pollutants along with metals act as an inhibitor for several phytohormones, such as alpha-amylase, gibberellins, auxins, and cytokinins, which act a crucial role in seed germination (Chandra et al., 2011). Additionally, significant changes were observed in several physiological parameters and revealed more accurate information about the harmful effects of pulp paper mill effluent and sludge in the pot experiment. The different concentrations of pulp paper mill sludge significantly $(P>0.05)$ contributed towards the percent $(\%)$ phytotoxicity of the pot experiment (figure 2 ).

\subsubsection{Estimation of morphological parameters}

In test plants, T.aestivum and B.campestris were tested at different concentrations of the sludge sample. The plant growth parameters (i.e. root length and shoot length) showed a significant decrease as compared to the control plant beyond above $50 \% \quad(\mathrm{w} / \mathrm{w})$ concentration shown in table 5 . The $25 \%(\mathrm{w} / \mathrm{w})$ concentration of paper mill sludge sample was tolerated by the T. aestivum and $B$. campestris plants and maximum increase in root length, shoot length and total dry weight were observed. Moreover, the T. aestivum and B. campestris plants treated with $75 \%(\mathrm{w} / \mathrm{w})$ pulp paper mill sludge 
Table 4 Effect of pulp paper mill sludge amended soil on seed germination of T. aestivum and B. campestris

\begin{tabular}{|c|c|c|c|c|}
\hline Sludge Concentration & Germination $\%$ & No of plants (one month) & No of plants (two month) & $\begin{array}{c}\% \text { Inhibition } \\
\text { (Phytotoxicity) }\end{array}$ \\
\hline \multicolumn{5}{|c|}{ Triticum aestivum } \\
\hline Control & 100 & $10 \pm 0.52^{\mathrm{a}}$ & $10 \pm 0.56^{\mathrm{a}}$ & $0.00 \pm 00^{\mathrm{e}}$ \\
\hline $25 \%$ & 100 & $10 \pm 0.52^{\mathrm{a}}$ & $9 \pm 0.52^{\mathrm{b}}$ & $33.84 \pm 0.23^{\mathrm{d}}$ \\
\hline $50 \%$ & 80 & $7 \pm 0.32^{\mathrm{b}}$ & $8 \pm 0.34^{\mathrm{c}}$ & $47.69 \pm 0.12^{\mathrm{c}}$ \\
\hline $75 \%$ & 60 & $6 \pm 0.22^{\text {cd }}$ & $4 \pm 0.18^{\mathrm{d}}$ & $66.15 \pm 0.23^{\mathrm{b}}$ \\
\hline $100 \%$ & 50 & $6 \pm 0.12^{\mathrm{d}}$ & $3 \pm 0.12^{\mathrm{e}}$ & $84.61 \pm 0.52^{\mathrm{a}}$ \\
\hline \multicolumn{5}{|c|}{ Brassica competries } \\
\hline Control & 100 & $10 \pm 0.52^{\mathrm{a}}$ & $10 \pm 0.42^{\mathrm{a}}$ & $0.00 \pm 00^{\mathrm{e}}$ \\
\hline $25 \%$ & 100 & $8 \pm 0.44^{\mathrm{b}}$ & $7 \pm 0.32^{\mathrm{b}}$ & $39.56 \pm 0.12^{\mathrm{d}}$ \\
\hline $50 \%$ & 70 & $7 \pm 0.24^{\text {cd }}$ & $6 \pm 0.22^{\mathrm{c}}$ & $53.74 \pm 0.32^{\mathrm{c}}$ \\
\hline $75 \%$ & 50 & $7 \pm 0.18^{d}$ & $4 \pm 0.16^{\mathrm{d}}$ & $78.66 \pm 0.22^{\mathrm{b}}$ \\
\hline $100 \%$ & 30 & $5 \pm 0.16^{\mathrm{e}}$ & $3 \pm 0.06^{\mathrm{e}}$ & $88.52 \pm 0.12^{\mathrm{a}}$ \\
\hline
\end{tabular}

Data are mean of three replicate \pm standard error of means; Means, followed by same letter in a column are not significantly different by Duncan's multivariate test (DMRT).

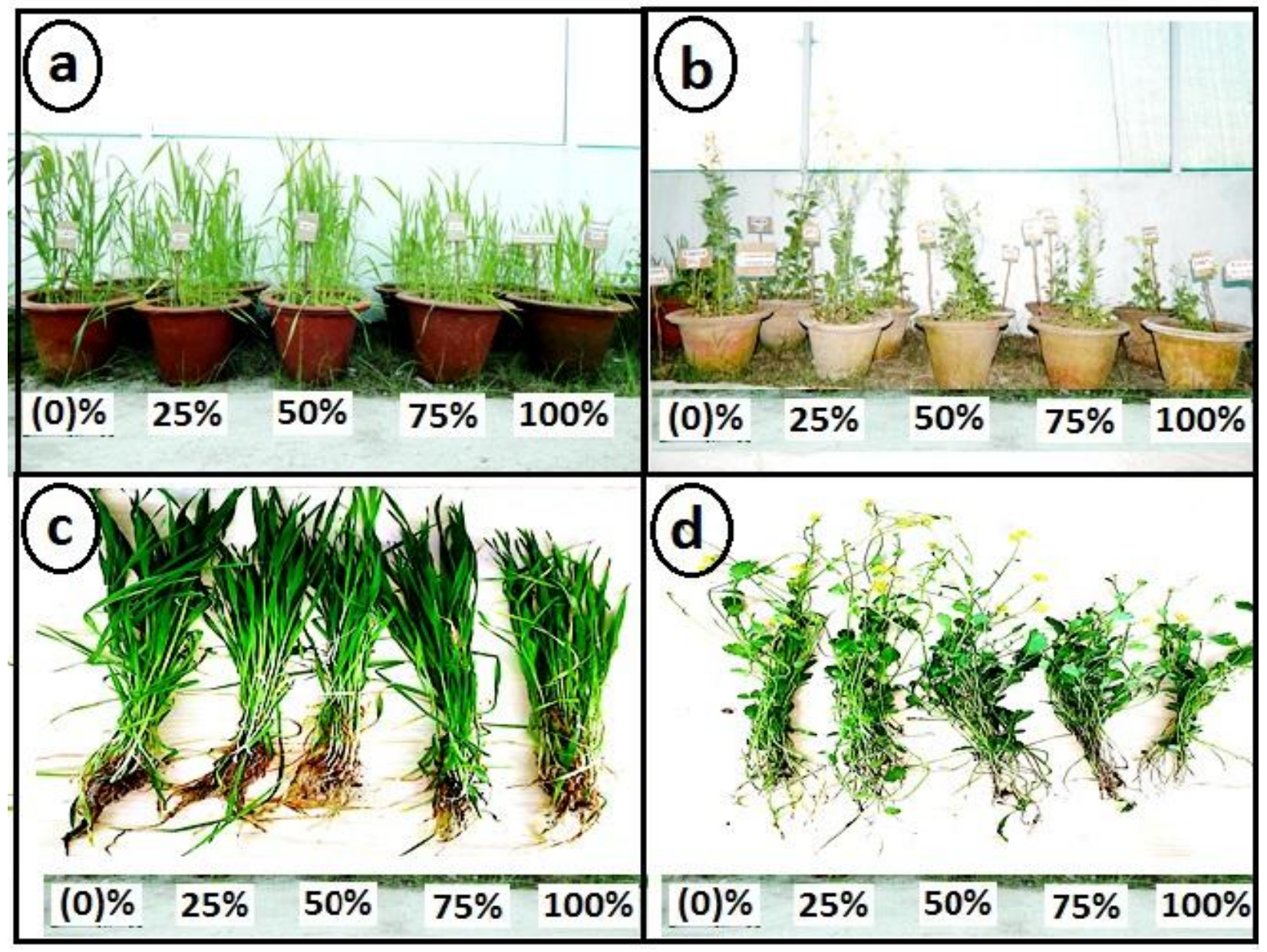

Figure 2 Pictures showing the pot experiment of T. aestivum (A, and C) and B. campestris (B and $\mathrm{D}$ ) which was conducted in the BBAU campus Lucknow.

Journal of Experimental Biology and Agricultural Sciences http://www.jebas.org 
Table 5 Effect of Pulp paper mill sludge on root length, shoot length and their respective biomass of T. acetivum and B. campestris

\begin{tabular}{|c|c|c|c|c|}
\hline \multicolumn{5}{|c|}{ Triticum aestivum } \\
\hline Sludge Concentration & Root length (cm) & Shoot length $\mathrm{cm}$ ) & Dry weight of roots (gm) & Dry weight of shoot (gm) \\
\hline Control & $13.33 \pm 0.94^{\mathrm{a}}$ & $22.00 \pm 0.81^{\mathrm{a}}$ & $0.26 \pm 0.005^{\mathrm{a}}$ & $0.54 \pm 0.001^{\mathrm{a}}$ \\
\hline $25 \%$ & $11.00 \pm 0.81^{\mathrm{b}}$ & $17.00 \pm 0.81^{\mathrm{b}}$ & $0.20 \pm 0.001^{\mathrm{b}}$ & $0.49 \pm 0.003^{b}$ \\
\hline $50 \%$ & $8.66 \pm 0.47^{c}$ & $10.33 \pm 1.24^{\mathrm{c}}$ & $0.13 \pm 0.001^{\mathrm{c}}$ & $0.43 \pm 0.001^{\mathrm{c}}$ \\
\hline $75 \%$ & $7.00 \pm 0.81^{\mathrm{d}}$ & $7.33 \pm 0.47^{\mathrm{d}}$ & $0.10 \pm 0.001^{\mathrm{d}}$ & $0.21 \pm 0.002^{\mathrm{d}}$ \\
\hline $100 \%$ & $5.66 \pm 0.47^{\mathrm{d}}$ & $4.33 \pm 0.47^{\mathrm{e}}$ & $0.04 \pm 0.001^{\mathrm{e}}$ & $0.14 \pm 0.001^{\mathrm{e}}$ \\
\hline \multicolumn{5}{|c|}{ Brassica competries } \\
\hline Control & $11.00 \pm 0.81^{\mathrm{a}}$ & $16.33 \pm 1.24^{\mathrm{a}}$ & $0.34 \pm 0.001^{\mathrm{a}}$ & $0.69 \pm 0.002^{\mathrm{a}}$ \\
\hline $25 \%$ & $8.33 \pm 0.47^{b}$ & $14.00 \pm 0.81^{\mathrm{b}}$ & $0.30 \pm 0.001^{\mathrm{b}}$ & $0.51 \pm 0.002^{\mathrm{b}}$ \\
\hline $50 \%$ & $6.66 \pm 1.88^{\mathrm{c}}$ & $10.33 \pm 0.94^{\mathrm{c}}$ & $0.28 \pm 0.002^{\mathrm{c}}$ & $0.47 \pm 0.002^{\mathrm{c}}$ \\
\hline $75 \%$ & $4.66 \pm 0.47^{\mathrm{d}}$ & $5.33 \pm 0.47^{\mathrm{d}}$ & $0.24 \pm 0.001^{\mathrm{d}}$ & $0.28 \pm 0.001^{\mathrm{d}}$ \\
\hline $100 \%$ & $2.33 \pm 0.47^{\mathrm{e}}$ & $3.33 \pm 0.47^{\mathrm{e}}$ & $0.14 \pm 0.002^{\mathrm{e}}$ & $0.12 \pm 0.001^{\mathrm{e}}$ \\
\hline
\end{tabular}

Data are mean of three replicate \pm standard error of means; Means, followed by same letter in a column are not significantly different by Duncan's multivariate test (DMRT).

Table 6 Effect of different concentration of sludge-amended soil on chlorophyll of T. aestivum and B. campestris

\begin{tabular}{|llccc|}
\hline & & Triticum aestivum & & Total chlorophyll \\
\hline Sludge Concentration & Chlorophyll a & Chlorophyll b & Chl a/Chl b & $0.641 \pm 0.017^{\mathrm{a}}$ \\
\hline Control & $0.478 \pm 0.006^{\mathrm{a}}$ & $0.158 \pm 0.005^{\mathrm{a}}$ & 3.44 & $0.522 \pm 0.014^{\mathrm{b}}$ \\
\hline $25 \%$ & $0.385 \pm 0.012^{\mathrm{b}}$ & $0.151 \pm 0.003^{\mathrm{ab}}$ & 3.12 & $0.436 \pm 0.012^{\mathrm{c}}$ \\
\hline $50 \%$ & $0.298 \pm 0.015^{\mathrm{c}}$ & $0.142 \pm 0.012^{\mathrm{c}}$ & 2.68 & $0.418 \pm 0.018^{\mathrm{de}}$ \\
\hline $75 \%$ & $0.264 \pm 0.003^{\mathrm{de}}$ & $0.114 \pm 0.001^{\mathrm{de}}$ & 2.22 & $0.412 \pm 0.012^{\mathrm{e}}$ \\
\hline $100 \%$ & $0.214 \pm 0.012^{\mathrm{e}}$ & $0.106 \pm 0.006^{\mathrm{e}}$ & 2.10 & $0.712 \pm 0.018^{\mathrm{a}}$ \\
\hline & & & 3.86 & $0.618 \pm 0.021^{\mathrm{b}}$ \\
\hline Control & $0.522 \pm 0.015^{\mathrm{a}}$ & $0.172 \pm 0.012^{\mathrm{a}}$ & 3.56 & $0.482 \pm 0.053^{\mathrm{c}}$ \\
\hline $25 \%$ & $0.456 \pm 0.023^{\mathrm{b}}$ & $0.154 \pm 0.006^{\mathrm{b}}$ & 3.52 & $0.466 \pm 0.006^{\mathrm{d}}$ \\
\hline $50 \%$ & $0.314 \pm 0.021^{\mathrm{c}}$ & $0.134 \pm 0.006^{\mathrm{c}}$ & 3.38 & $0.453 \pm 0.016^{\mathrm{e}}$ \\
\hline $75 \%$ & $0.288 \pm 0.012^{\mathrm{d}}$ & $0.122 \pm 0.017^{\mathrm{d}}$ & 3.17 & ${ }^{\mathrm{d}}$ \\
\hline $100 \%$ & $0.232 \pm 0.016^{\mathrm{e}}$ & $0.112 \pm 0.003^{\mathrm{e}}$ & & \\
\hline
\end{tabular}

Data are mean of three replicate \pm standard error of means; Means, followed by the same letter in a column are not significantly different by Duncan's multivariate test (DMRT).

have shown vigorous growth initially but later reduced growth, delayed flowering and fruiting was observed as compared to the control. The different concentrations of pulp paper mill sludge significantly $(P>0.05)$ contributed towards \% phytotoxicity of root and shoot. The inhibition of seed germination and plant growth at higher concentrations of sludge-amended soils may be due to the high salt concentrations, toxic pollutants in pulp and paper mill sludge creating high osmotic pressure and toxicity. The high osmotic pressure and pollutant toxicity caused inhibition of seed germination and their growth parameters. Similar observations have been reported earlier by Chandra et al. (2008).

\subsubsection{Effect on photosynthetic pigments}

The photosynthetic surface area and leaf chlorophyll content were the key factors for determining dry matter production of T. aestivum and B. campestris. There was an increase in chlorophyll-a, complete band chlorophyll content in leaves $T$. aestivum and B. campestris plants at 30 and 60 days of development in different concentration of pulp paper mill effluent and sludge. However, the pigment concentration decreased significantly above $50 \%$ concentration of sludge after 60 to 90 days of growth period as compared to the control as shown in table 6 . The highest photosynthetic pigment 
Table 7 Different concentration pulp paper mill effluent toxicity on Tubifex-tubifex worm

\begin{tabular}{|lcccccccc|}
\hline $\begin{array}{l}\text { Concentration/ } \\
\text { Time (hrs.) }\end{array}$ & $0 \mathrm{~h}$ & $24 \mathrm{~h}$ & $48 \mathrm{~h}$ & $72 \mathrm{~h}$ & $96 \mathrm{~h}$ & Measurement & Effects & LC50 \\
\hline $0 \%$ & $19.33 \pm 0.57$ & $18.66 \pm 1.15$ & $18.33 \pm 1.15$ & $17.66 \pm 0.57$ & $17.33 \pm 1.15$ & Mortality & No change & Non-Toxic \\
\hline $25 \%$ & $17.66 \pm 0.57$ & $15.66 \pm 0.57$ & $12.33 \pm 0.57$ & $8.33 \pm 1.52$ & $3.33 \pm 1.52$ & Mortality & $\begin{array}{c}\text { Physical } \\
\text { damage }\end{array}$ & $\begin{array}{c}\text { Slightly } \\
\text { Toxic }\end{array}$ \\
\hline $50 \%$ & $15 \pm 2.64$ & $13.66 \pm 1.15$ & $9.66 \pm 1.52$ & $6.66 \pm 0.57$ & $1.66 \pm 0.57$ & Mortality & $\begin{array}{c}\text { Break down } \\
\text { of cell } \\
\text { membrane }\end{array}$ & $\begin{array}{c}\text { Moderately } \\
\text { Toxic }\end{array}$ \\
\hline $75 \%$ & $13.33 \pm 1.15$ & $10.33 \pm 0.57$ & $6.66 \pm 1.15$ & $2.33 \pm 0.57$ & $0.66 \pm 0.57$ & Mortality & $\begin{array}{c}\text { Cell } \\
\text { damage }\end{array}$ & $\begin{array}{c}\text { Highly } \\
\text { Toxic }\end{array}$ \\
\hline $100 \%$ & $10.33 \pm 0.57$ & $7.66 \pm 0.57$ & $2.66 \pm 1.15$ & $0.33 \pm 0.57$ & $0.00 \pm 00$ & Mortality & $\begin{array}{c}\text { Burst and } \\
\text { cell damage }\end{array}$ & $\begin{array}{c}\text { Extremely } \\
\text { Toxic }\end{array}$ \\
\hline
\end{tabular}

$0 \mathrm{~h}$
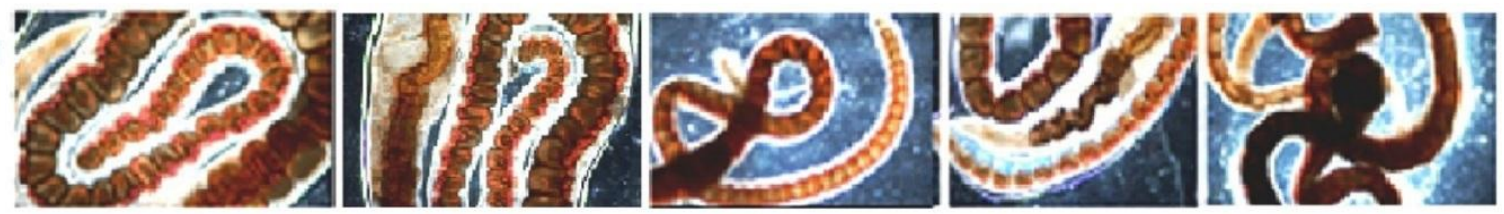

$48 \mathrm{~h}$
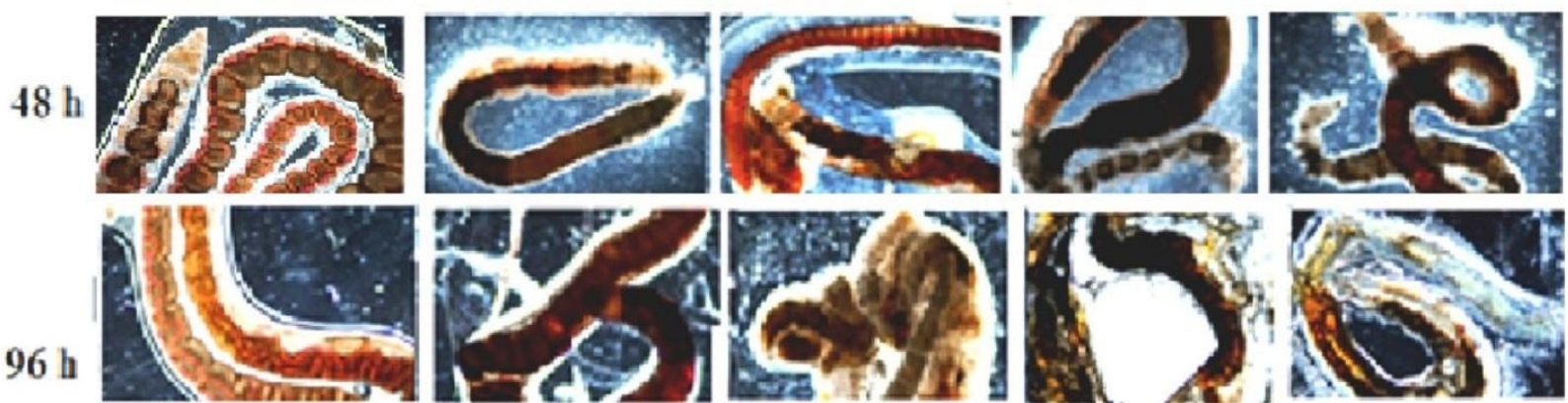

Control $(0 \%)$

$25 \%$

$50 \%$

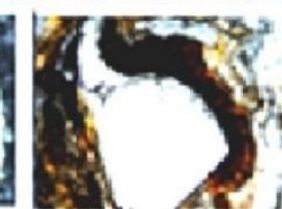

$75 \%$

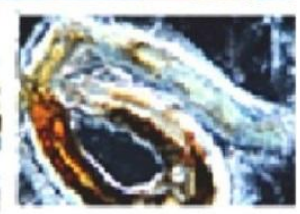

$100 \%$

Figure 3 Tubifex-tubifex toxicity test was performed with different concentration of effluent and morphological study and toxic properties was observed after 24 hours on the first day, 48 hours in the second day, 72 hour in the third day and 96 hours in the fourth day.

(chlorophyll-a, band total chlorophyll) formation was noticed up to $25 \%$ (T. aestivum and B. campestris plants) at 60 days of the growth period and that was compared with control. Due to continuous increases in sludge concentrations in pot, significantly photosynthetic pigments were decreased in the plant. However, these metals, which were acting as nutrients crossed the threshold limit at high sludge concentrations and work as toxic agents through direct inhibition of photosynthesis (Chandra et al., 2008).

\subsection{Toxicity of paper mill effluent on Tubifex-tubifex}

Laboratory toxicity testing was also an essential tool for assessing the potential effect of chemicals on ecological systems through environmental evaluation (Shuhaimi-Othman et al., 2012a). Several freshwater pollution evaluations and toxicity testing were recorded with ligochaetes, particularly from the tubifex and Lumbriculidae families, such as Tubifex-tubifex and Lumbriculus variegates (Khangarot, 1991; Mosleh et al., 2007; Sardo \& Soares, 2011). The high sediment contamination of different concentrations of paper mill effluent triggered the autotomy process and showed a clear reduction in growth rate and other activity of tubifex worm. This study showed the toxicity of different concentrations $(25 \%, 50 \%, 75 \%$, and $100 \%)$ of paper mill effluent compared with control (tap water) shown in figure 3 and table 7.

During the test period, tubifex worms have remained active in control. At the bottom of the test container, they were clustered and showed typical tubifex movement. At the starting of the experiment, test animals remained separated in the higher concentrations of pulp paper mill effluent and showed rapid twisting movement. The later intoxication phase was the worm's reduced tactile movements. The body was segmented and degenerated, and death occurred without any other noticeable signs as it may be due to the presence of chlorinated toxic compounds in the effluent. The causes of toxicity of high concentration of heavy metals were accumulated in body parts of the worms (ShuhaimiOthman et al., 2012b). After 24 hours of exposure, morphological 
changes, hemoglobin content disappeared at the lethal concentrations of pulp paper mill effluent, cell bursting, and the back of the body became white, with body disintegration were observed. In general, disintegration begins from the back of the body and progresses to the front. However, these similar results in tubifex worms were also reported by Khangarot, (1991). Due to the rapid increase in the concentration of paper mill effluent the worms getting dead.

\section{Conclusions}

In the present study, toxic organic pollutants were detected from the pulp paper industry. The discharged effluent contains different chemicals that have endocrine-disrupting properties. This is the first report on the detection of persistent organic pollutants and their toxicity in agricultural crop and aquatic ecosystems. However, due to the presence of organic chemical compounds in the affluent, there is an increase in the BOD, COD, and TDS level in the aquatic resources and the aquatic organisms (Tubifextubifex) get affected in terms of their reproduction and other metabolic activities were stopped and they may be lost or died. Besides, these chemicals may also increase the toxicity level in the receiving water sources. The crop plants ( $T$. aestivum and $B$. campestris) are also affected due to the excessive use of sludge and effluent in the crop field as irrigated water in undeveloped areas where there is no proper irrigation system available. The affected crop has been destroyed by its root length, shoot length, and seed quality. The chemical pollutants of the effluent may also reach the body of higher animals through the food chain. The effect of effluent was noticed and found roots of the plants were reduced and tubifex worms cell wall became whitened and burst in above $25 \%$ concentration of effluent and sludge. Hence, this research article is very useful for the researchers for the understanding of the pollutants of paper mill effluent and their toxicity in the environment.

\section{Conflict of interest}

The authors declare that there is no conflict of interest regarding the publication of this manuscript.

\section{Ethical approval}

This article does not contain any studies with human participants or animals performed by any of the authors.

\section{Acknowledgement}

This study was funded by NFPwD F. No. 01-01/2019-Sch. to Ajay Kumar Singh Ph.D. scholar; University Grant Commission, New Delhi, to Adarsh Kumar Ph.D. scholar and the financial assistance from DBT, New Delhi, India Letter No. BT/PR18896/BCE/8/1372/2016 dated 2803-2018 to Prof. Ram Chandra, is highly acknowledged.

\section{References}

APHA (2005) Standard Methods for the Examination of Water and Wastewater, 21st edn. American Public Health Association, Washington, DC.

Arnon DI (1949) Copper enzymes in isolate chloroplasts.Polyphenol oxidase in Beta vulgaris. Plant Physiology 24: 1-15.

Chandra R, Abhishek A (2010) Bacterial decolorization of black liquor in axenic and mixed condition and characterization of metabolites. Biodegradation 22:603-611.

Chandra R, Abhishek A, Sankhwar M (2011) Bacterial decolorization and detoxification of black liquor from rayon grade pulp manufacturing paper industry and detection of their metabolic products. Bioresource Technology 102:6429-6436.

Chandra R, Raj A, Yadav S, Patel DK (2009) Reduction of pollutants in pulp paper mill effluent treated by PCPdegrading bacterial strains. Environmental Monitoring and Assessment 155: 1-11.

Chandra R, Shail Singh, Abhay Raj (2006) Seasonal bacteriological analysis of Gola River water contaminated with pulp paper mill waste in Uttaranchal, India. Environmental Monitoring and Assessment 118: 393-406.

Chandra R, Singh R (2012) Decolourisation and detoxification of rayon grade pulp paper mill effluent by mixed bacterial culture isolated from pulp paper mill effluent polluted site. Biochemical Engineering Journal 61:49-58.

Chandra R, Yadav S (2017) Phytoextraction potential of heavy metals by native wetland plants growing on chlorolignin containing sludge of pulp and paper industry. Ecological Engineering 98:134-145.

Chandra R, Yadav S, Mohan D (2008) Effect of distillery sludge on seed germination and growth parameters of green gram (Phaseolusmungo L.). Journal of Hazardous Materials 152 431-439.

Chow PS, Landhausser SM (2004) A method for routine measurements of total sugar and starch content in woody plant tissues. Tree Physiology 24: 1129-1136.

Colette W, Kevin M (2017) A mechanistic theory for aquatic food chain length. Nature Communications 8:DOI: 10.1038/s41467017-02157-0.

CPPA (1974) Canadian Pulp and Paper Association, Technical section standard method H5P Montreal, Canada.

Duncan DB (1955) Multiple range and multiple F-tests. Biometrics 11: 1-42. 
Holt E, Von Der, Recke R, Vetter W, Hawker D, Alberts V, Kuch B, Weber R, Gaus C (2008) Assessing dioxin precursors in pesticide formulations and environmental samples as a source of octachlorodibenzop dioxin in soil and sediment. Environmental Science \& Technology 42:1472-1478.

Hossain K, Ismail N (2015) Bioremediation and Detoxification of Pulp and Paper Mill Effluent: A Review. Research Journal of Environmental Toxicology 9:113-134. 10.3923/rjet.2015.113.134.

Jaramillo M, Restrepo T (2017) Wastewater Reuse in Agriculture: A Review about Its Limitations and Benefits. Sustainability (Switzerland) 9. 10.3390/su9101734.

Karrasch B, Parra O, Cid H, Mehrens M, Pacheco P, Urrutia R (2005) Effect of pulp and paper mill effluents on the micro plankton and microbial self-purification capabilities of the Biobio River, Chile. The Science of the Total Environment (1-3):194-663 208.

Khangarot BS (1991) Toxicity of Metals to a Freshwater Tubifex Worm, Tubifextubifex (Muller). Bulletin of Environmental Contamination and Toxicology 46:906-912.

Kim S, Thiessen PA, Bolton EE, Chen J, Fu G, Gindulyte A, Han L, He J, He S, Shoemaker BA, Wang J, Yu B, Zhang J, Bryant SH (2016) PubChem substance and compound databases. Nucleic Acids Research 44(D1):D1202-D1213.

Kumar A, Singh AK, Chandra R (2020b) Comparative analysis of residual organic pollutants from bleached and unbleached paper mill wastewater and their toxicity on Phaseolusaureus and Tubifextubifex, Urban Water Journal, DOI:10.1080/1573062X.2020.1836238.

Lindholm-Lehto PC, Knuutinen JS, Ahkola HSJ, Herve SH (2015) Refractory organic pollutants and toxicity in pulp and paper mill wastewaters. Environmental Science and Pollution Research 22: 6473-6499 (2015). https://doi.org/10.1007/s11356-015-4163-x

Livernoche D, Jurasek L, Desrochers M, Dorica J, Veliky IA (1983) Removal of color from Kraft mill wastewaters with cultures of whiterot fungi and with immobilized mycelium of Coriolusversicolor Biotechnology and Bioengineering 25:2055-2065.

Mosleh YY, Paris-Palacios S, Ahmed MT, Mahmoud FM, Osman MA and Biagianti-Risbourg S (2007) Effects of chitosan on oxidative stress and metallothioneins in aquatic worm Tubifex tubifex (Oligochaeta, Tubifexae). Chemosphere 67: 167-175.

Nicholson FA, Smith SR, Alloway B (2003) An inventory of heavy metals inputs to agricultural soils in England and Wales. Science of the Total Environment 311:205-219.

Nicola S, Baoshan X, Huang PM (2006) Biophysico-Chemical Processes Involving Natural Nonlifiidulfitving Organic Matter in Environmental Systems New York: IUPAC.
Oljira T, Muleta D, Jida M (2018) Potential Applications of Some Indigenous Bacteria Isolated from Polluted Areas in the Treatment of Brewery Effluents. Biotechnology Research International Article ID 9745198, Pp.13.https://doi.org/10.1155/2018/9745198.

Pearl IA, Benson HK (1940) The determination of lignin in sulphide pulping liquor. Paper Trade Journal 111: 35-36.

Pokhrel D, Viraraghavan T (2004) Treatment of pulp and paper mill wastewater-a review. Science of the Total Environment $333: 37-58$.

Raj A, Krishna Reddy MM, Chandra R (2007) Decolourisation and Treatment of Pulp and Paper Mill Effluent by Lignin-Degrading Bacillus sp. Journal of Chemical Technology and Biotechnology $82: 399$ - 406. 10.1002/jctb.1683.

Ramana S, Biswas AK, Kundu K, Saha JK, Yadav RBR (2002) Relative efficacy of distillery effluent on seed germination in some vegetable crops. Bioresourse Technology 82 273-275.

Reza SK, BaruahUtpal, Singh SK (2015) Accumulation and Translocation of Heavy Metals in Soil and Crop Irrigated with Paper Mill Effluents. Journal of the Indian Society of Soil Science 63:242. 10.5958/0974-0228.2015.00033.X.

Ruggicro P, Sarkar JM, Bollag JM (1989) Quantification of the effect of soil organic matter content on soil productivity. Soil Science 147:361.

Sardo AM, Soares AMVM (2011) Short- and long-term exposure of Lumbriculusvariegatus (Oligochaete) tometal lead: Ecotoxicological and behavioral effects. Human and Ecological Risk Assessment: An International Journal17: 1108-1123.

Shuhaimi-Othman M, Nadzifah Y, Umirah NS, Ahmad AK (2012b) Toxicity of Metals to an Aquatic Worm, Naiselinguis (Oligochaeta, Naididae). Research Journal of Environmental Toxicology 6: 122-132.

Shuhaimi-Othman MY, Nadzifah NS, Umirah and Ahmad (2012a) Toxicity of metals to tadpoles of common Sunda toad, Duttaphrynusmelanostictus.Toxicology. Environmental Chemistry 94: 364-376.

Singh AK, Chandra R (2019) Pollutants released from the pulp paper industry: Aquatic toxicity and their health hazards. Aquatic Toxicology $211202-216$.

Singh P, Thakur IS (2004) Removal of colour and detoxification of pulp and paper mill effluent by microorganisms in two step bioreactor. Journal of scientific and industrial research 63:941-944. 
Singhal A, Thakur IS (2009) Decolourisation and detoxification of pulp and paper mill effluent by Emericellanidulans Var. nidulans Journal of Hazardous Materials 171:619-625.

Subramani A, Saravanan S TamizhiniyanP, Lakshmanachary AS (1997) Influence of heavy metals on germination and early seedling growth of Vignamungo(L.) Hepper. Pollution Research 16(1):29-31.

US Environmental Protection Agency USEPA (2012) Endocrine Disruptor Screening Program, Universe of Chemicals for Potential Endocrine Disruptor Screening and Testing, Jointly developed by the Office of Chemical Safety \& Pollution Prevention, the Office of Water and the Office of Research and Development, Pp.1-176.

Wong JWC, Li GX, Wong MH (1996) The growth of Brassica chinensisin heavy metal contaminated sewage sludge compost from Hong-Kong. Bioresourse Technology 58 309-313.

Wong SC, Li XD, Zhang G (2003) Heavy metals in agricultural soils of the Pearl river Delta, South China. Environment Pollution 119:33-44.
Wurtz CB, Bridges CH (1961) Preliminary results from macroinvertebrate bioassays. Proceedings of the Pennsylvania Academy of Science. 35:51-56.

Yadav S, Chandra R (2018) Detection and assessment of the phytotoxicity of residual organic pollutants in sediment contaminated with pulp and paper mill effluent. Environmental Monitiring Assessement 190:581.

Yang, Jen-Hung, Chia-Hue Lee, Nancy Monteiro-Riviere, Jim Riviere, Chau-Loong Tsang, Chi-Chung Chou (2006) Toxicity of jet fuel aliphatic and aromatic hydrocarbon mixtures on human epidermal keratinocytes: Evaluation based on in vitro cytotoxicity and interleukin- 8 release. Archives of toxicology 80:508-23. 10.1007/s00204-006-0069-1.

Zhang Jing, Xie Ping Tao Min Guo, Longgen, Chen, Jun, Li, Li, Zhang, Xuezhen, Zhang, Lu (2013) The Impact of Fish Predation and Cyanobacteria on Zooplankton Size Structure in 96 Subtropical Lakes. PloS one 8:e76378. 10.1371/journal.pone.0076378. 